\title{
jC
}

Jurnal Civics: Media Kajian Kewarganegaraan

https://journal.uny.ac.id/index.php/civics/index

1829-5789 (print)

2541-1918 (online)

\section{Pancasila dan toleransi pada tradisi keagamaan masyarakat Yogyakarta}

\author{
Nurainun Mangunsong a, 1*, Vita Fitria ${ }^{\text {b, }}$, \\ a, b Fakultas Syari'ah dan Hukum UIN Sunan Kalijaga Yogyakarta, Indonesia \\ ${ }^{1}$ nurainun.mangunsong@uin-suka.ac.id *; vitafitria08@gmail.com \\ *korespondensi penulis
}

\begin{tabular}{ll}
\hline \multicolumn{2}{l}{ Informasi artikel } \\
\hline Sejarah artikel: & \\
Diterima & $: 02-01-2019$ \\
Revisi & $: 05-03-2019$ \\
Dipublikasikan & $: 31-03-2019$ \\
\hline
\end{tabular}

Kata kunci:

Toleransi

Tradisi keagamaan

Kohesi sosial

\begin{abstract}
ABSTRAK
Artikel ini mengkaji tentang nilai-nilai toleransi keagamaan yang muncul dalam masyarakat sinkretis Girikarto dan puritanis Kotabaru Yogyakarta. Penelitian ini mengambil objek penelitian Masyarakat Budha dan Islam di wilayah Girikarto serta Huria Kristen Batak Protestan (HKBP) dan Yayasan Masjid Syuhada Kotabaru Yogyakarta. Metode penelitian empirik ini dilakukan dengan wawancara secara mendalam dan observasi lapangan secara langsung dalam kehidupan keluarga, sosial, dan keagamaan masyarakat. Pendekatan yang digunakan adalah antropologis. Hasil penelitian menunjukkan bahwa toleransi merupakan konsep keagamaan yang berbaur dengan pluralitas tradisi Jawa (Hindu-Budha, animisme, dinamisme, dan Islam) yang membentuk ide, nilai, tradisi, sistem sosial sebagai satu kesadaran hidup damai dan rukun di antara masyarakat, khususnya Yogyakarta. Kemajemukan menjadi suatu keniscayaan. Pancasila diyakini merupakan filosofi dan ideologi yang mempersatukan kemajemukan itu. Pancasila merupakan kristalisasi nilainilai budaya yang tumbuh dan berkembang dalam kehidupan keagamaan masyarakat. Toleransi merupakan pemaduan nilai agama dan budaya yang dipegang teguh dengan baik.
\end{abstract}

Keywords:

Tolerance

Religious-tradition

Social cohesion

\section{ABSTRACT}

This article studies on religious tolerance values that emerge in syncretism society Girikarto and puritanism one in Kotabaru Yogyakarta. This research takes the object on Girikarto Buddhism and Muslim, and Huria Batak Protestant (HKBP) and Syuhada mosque foundation, Kotabaru Yogyakarta. This empirical method is applied by deep interview and immediate observation of social and religious reality. The approach used in anthropology. The result of the research shows that tolerance is a religious concept that interacts with Javanese plurality traditions (Hinduism-Buddhism, animism, dynamism, and Islam) that create ideas, values, traditions, the social system as awareness to live peacefully among society, especially in Yogyakarta. The diversity is a reality. Pancasila is believed as a philosophy and ideology that unify this diversity. Pancasila is the crystallization of cultural values that grow and develop in society life. Tolerance is a mixture of religious and cultural values that held strongly

\section{Copyright (C) 2019 Nurainun Mangunsong dan Vita Fitria}

\section{Pendahuluan}

Yogyakarta selain mendapat sebutan sebagai kota pelajar, juga merupakan kota yang kental dengan nilai-nilai tradisi dan pluralitas keagamaan. Tradisi budaya Jawa yang guyub dan komunal serta budaya peninggalan kolonialis Belanda yang rasional dan positivistik sangat mempengaruhi cara pandang masyarakat Yogyakarta yang cenderung toleran dan inklusif. Yogyakarta banyak menyimpan peninggalan sejarah seperti bangunan Kraton, bangunan gedunggedung pendidikan, rumah ibadah, alun-alun, museum-museum, dan arsitektur tata ruang kota yang artistik klasik dan kukuh. Begitu peninggalan non-fisik berupa karya seni dan budaya, karakteristik perilaku masyarakat yang halus, sopan, dan akomodatif. 
Peninggalan-peninggalan Belanda tersebut turut memberi kontribusi bagi kemajuan budaya, tata kota dan perkembangan pendidikan. Perkembangan dunia pendidikan dan arsitektur bangunan telah menjadikan kota ini sebagai kota pelajar yang menghasilkan banyak ilmuwan namun tetap akomodatif dalam mempertahankan nilainilai budaya dan pluralitas masyarakatnya.

Di wilayah DIY, terdapat sekelompok masyarakat keagamaan yang masih menjunjung tinggi nilai-nilai toleransi itu. Yakni masyarakat Budha dan Islam Girikarto Gunungkidul dan masyarakat Protestan Batak HKBP dan Yayasan Masjid Syuhada Kotabaru Yogyakarta. Masyarakat Girikarto dikenal sebagai masyarakat yang berkeyakinan sinkretis, sementara HKBP dan Yayasan Masjid Syuhada dikenal sebagai kaum puritan. Sinkretis adalah masyarakat yang berpegang pada nilai-nilai budaya, sedangkan puritanisme berpedoman pada nilai-nilai agama secara kuat sebagai dasar pedoman hidup (Sutiyono, 2011). Dalam relasi sosial beragama yang pluralis, keduanya memiliki karakter yang berbeda, dimana sinkretis lebih inklusif dan cenderung toleran, sebaliknya puritanism lebih eksklusif dan keras dalam relasi dengan masyarakat yang pluralis. Yogyakarta memiliki karakter masyarakat yang unik. Keunikannya pada relevansi budaya yang tumbuh dan berkembang dalam kehidupan beragama dan kemajuan dunia pendidikan di Yogyakarta sebagai kota pelajar.

Agama tidak lain sebuah sistem simbol yang memberikan penganutnya ide-ide (Sutiyono, 2011). Simbol-simbol dalam agama tersebut menciptakan perasaan dan motivasi yang kuat, mudah menyebar dan tidak mudah hilang dalam diri seseorang (penganutnya), atau simbol agama tersebut menyebabkan penganutnya melakukan sesuatu (misalnya ritual), karena dorongan perasaan yang sulit didefinisikan dan juga sulit dikendalikan. Kekuatan perasaan itu muncul karena agama membentuk konsepkonsep tentang tatanan seluruh eksistensi. Maksud agama terpusat pada makna final (ultimate meaning), suatu tujuan pasti bagi dunia (Geertz, 1973).
Max Weber yang mencatat tentang visi substansi tindakan sosial (in order to motive), menegaskan bahwa dasar tindakan meliputi beberapa hal yakni rasional instrumental, rasional nilai, afeksi dan tradisional (dalam Jones, Bradbury, \& Le Boutillier, 2009). Merton juga menegaskan bahwa dalam struktur fungsional, ada saling ketergantungan agar tetap bertahan. (Merton, Robert, 1967). Agama dalam perspektif budaya Geertz dipengaruhi oleh pandangan Max Weber tentang the structure of social action, yang kemudian dikembangkan oleh Parson. Parson (1961)mengembangkan pandangan bahwa seluruh kelompok manusia terdiri dari tiga level bentuk organisasi, yakni (1) kepribadian individual yang berasal dan dibangun oleh (2) sistem sosial, yang pada gilirannya sistem ini akan dikontrol oleh (3) satu "sistem kebudayaan" yang terpisah. Sistem kebudayaan yang berisi jaringan tata nilai, simbol, kepercayaan-kepercayaan yang kompleks ini memiliki integrasi tak terpisahkan dengan individu dan masyarakat (Parsons, 1961).

Merunut tentang sejarah toleransi antara agama dan negara di Indonesia, tak lepas dari sejarah dirumuskannya dasar negara yang mengalami perdebatan dari dua kubu. Kelompok pertama, adalah kelompok nasionalis Islam yang menginginkan agar negara Indonesia berdasar atas "Ketuhanan dengan kewajiban menjalankan syariat Islam bagi pemeluk-pemeluknya," dan kelompok kedua, adalah nasionalis sekuler yang menolak tujuh kata tersebut sebagai representasi mayoritas muslim semata. Nasionalis sekuler berpandangan bahwa dasar negara adalah kebangsaan bangsa Indonesia yang beragam. Ketuhanan harus merepresentasikan semua agama dan keyakinan yang beragam itu. Mereka yang menolak usulan nasionalis Islam itu diwakili dari kelompok masyarakat Indonesia bagian Timur. Melihat situasi yang tidak kondusif dan mengarah pada satu perpecahan, maka Hatta bersama Kasman Singodimedjo mencoba melakukan perundingan kembali dengan kelompok Nasional Islam. Dari perundingan itu, disepakati untuk menghapus tujuh kata dalam redaksi Piagam Jakarta, akan

90| Jurnal Civics: Media Kajian Kewarganegaraan 
tetapi tetap menambahkan "Ketuhanan" dengan "Yang Maha Esa" (Kamaruddin, 2013).

Antara kebangsaan dan keislaman merupakan dua konsep yang tidak perlu diperdebatkan lagi. Keduanya saling mengisi dan menunjang bagi peradaban bangsa Indonesia. Kebangsaan dan keislaman merupakan konsep integral yang saling bersimbiosis secara mutualistis. Padu padan keduanya dimanifestasikan dalam Pancasila. Pancasila mengapresiasi Islam, membuka peluang legislasi di tingkat nasional, termasuk lokal. Spirit kemanunggalan itu dilandasi oleh integralisme sehingga keragaman apapun dapat dipersatukan melalui Pancasila (Budiyono, 2014).

Secara konstitusional, "Ketuhanan" adalah refleksi dari keagamaan bangsa Indonesia yang majemuk dan multikultural. Bangsa dan negara Indonesia tidak boleh menghianati Bhinneka Tunggal Ika sebagai salah satu dari empat konsensus nasional yang mendasari pendirian Indonesia merdeka. Masing-masing agama bisa menggunakan perspektifnya dalam memaknai konsep "Ketuhanan". Dalam Islam, "Ketuhanan" adalah manifestasi keesaan atau wahid. Alwahid itu tidak ditemukan dalam pemahaman sifat Tuhan pra-Islam (Kartohadiprodjo, 2010). Penerapan ideologi Islam dalam Pancasila sila pertama tidaklah mengandung makna menutup hak hidup bagi pemeluk agama lainnya di Indonesia. Justru menerapkan ideologi Islam dalam sila pertama Pancasila memberikan ruang hidup bagi pemeluk agama lain di Indonesia. Islam mengajarkan hubungan baik dengan sesama manusia (Fuad, 2012)

Dari uraian di atas jelas bahwa agama menjadi elemen dasar dalam negara hukum Pancasila. Pancasila harus dimaknai sebagai bagian dari nilai luhur asli bangsa Indonesia yang terus berkembang dalam lintas peradaban. Keragaman adalah sebuah realitas yang tidak bisa dihindari. Oleh karenanya, keragaman menjadi satu keniscayaan bagi Bangsa Indonesia. Berdasarkan catatan Wahyuni (dalam Ruhana, 2016), masyarakat Desa Girikarto tersebut secara umum berjumlah kurang lebih 751.316 orang, beragama Islam 716.783 orang atau mencapai 95,4\%, beragama Kristen berjumlah 15.152 orang atau 2\%; yang beragama Katolik 16.660 orang atau 2,2\%; Hindu berjumlah 1.962 orang atau $0,2 \%$; dan yang beragama Buddha berjumlah 443 orang atau $0,05 \%$; sedangkan yang tidak beragama 324 orang atau $0,057 \%$. Dari 443 orang yang beragama Buddha di Kabupaten Gunung Kidul tersebut, tersebut 360 tinggal menjadi satu komunitas di Kecamatan Panggang. Sementara, Kelurahan Gondokusuman, Kotabaru Yogyakarta, posisi penduduk dalam wilayah perkotaan, memiliki keragaman stratifikasi sosial, ekonomi, budaya, agama, dan pendidikan. Stratifikasi ekonomi dan pendidikan yang jauh lebih tinggi dibandingkan masyarakat pedesaan, masyarakat Kotabaru dipandang lebih rasional dalam pola relasi agama, budaya, dan pandangan pengetahuannya. Pemeluk agama Islam umumnya adalah Muhammadiyah, sementara Kristiani adalah Protestan. Kondisi sosiologis itu, menentukan masyarakat Kotabaru termasuk masyarakat yang puritanis. Namun demikian, kedua umat beragama yakni Muslim dan Protestan tetap dapat hidup secara toleran. Indikator toleransi itu terlihat pada persandingan bangunan peribadatan Masjid dan Gereja secara berdekatan atau sampingan dan minimnya konflik agama.

Dari pemaparan di atas, yang menjadi kajian menarik untuk diteliti adalah mengenai toleransi yang tertanam kesadaran yang tertanam dari nilai-nilai Pancasila atau agama itu sendir dan mengenai modal dasar mewujudkan toleransi antar warga negara tersebut.

\section{Metode}

Penelitian ini merupakan penelitian lapangan (field research) dengan pendekatan kualitatif dengan lokasi di dua tempat yaitu di Desa Girikarto Panggang Gunungkidul dan Kecamatan Kota Baru Yogyakarta. Lokasi pertama di desa Girikarto, penulis mengambil sampel di Dukuh Wiloso dan Dukuh Pundung. Pada wilayah lokasi tersebut berdiri 5 buah masjid, 8 Musala, 1 Wihara dan 1 Gereja. Lokasi kedua di Kelurahan 
Gondokusuman Kotabaru Yogyakarta, terdapat Gereja dan Masjid yang cukup besar di lingkungan wilayah Kota Yogyakarta, yaitu GHPB (Gereja Huria Protestan Batak ) dan Masjid Syuhada.

Untuk melihat bagaimana modal dan pola toleransi yang diterapkan oleh masyarakat dalam dua wilayah itu, penulis menggunakan wawancara mendalam terhadap para pemuka agama, kepala dukuh dan masyarakat yang dipilih secara representatif. Analisis data dilakukan secara induktif. Toleransi keagamaan yang terbangun dengan baik antara umat Islam-Budha di wilayah Girikarto, maupun antara umat Kristen-Islam di wilayah Kota Baru, sudah terjalin selama bertahun-tahun. Dalam penggalian data secara lebih spesifik atas pemahaman masyarakat terhadap Pancasila dan Agama yang mereka anut, penulis menggunakan pendekatan sosiologi dan antropologi. Artinya, fenomena keagamaan, praktik-praktik ibadah, kehidupan beragama, didekati dengan melihat konteks sosial dan budaya yang melingkupinya. Apakah manifestasi keagamaan memiliki relasi sosial budaya terhadap masyarakat penganut agama, atau sebaliknya konteks sosial budaya masyarakatlah yang menentukan keagamaan seseorang.

\section{Hasil dan Pembahasan}

Girikarto, sebagai salah satu desa di Kecamatan Panggang, memiliki keragaman agama dan keyakinan dengan tradisi-tradisi yang unik. Tradisi para leluhur hingga kini masih tetap terpelihara dengan baik, sehingga kerukunan antar umat beragama tetap terjaga di tengah arus perubahan dan kemajuan teknologi informasi. Kuatnya toleransi itu didasarkan pada pandangan para leluhur atas Ketuhanan Semesta bagi umat manusia yang beragam namun berasal dari satu keturunan dan tujuan hidup yang sama yakni kerukunan, keteraturan, keseimbangan, dan kedamaian. Pandangan keagamaan itu merupakan kristalisasi budaya Jawa guyub, rukun, agawe sentosa.

Para leluhur Budha dulu mengajarkan rasa persaudaraan dan kerja sama antar umat. Pendirian rumah ibadah, baik masjid maupun wihara dilakukan bersama-sama secara bergotong royong. Kalau ada sripah, seluruh penduduk (baik Islam, Budha, Kristen, dan penganut kepercayaan) Girikarto bersamasama berkunjung membawa bingkisan sebagai bentuk solidaritas turut berbelasungkawa. Di antara mereka ikut membantu di dapur atau merangkai kembang untuk hiasan keranda jenazah. Meskipun ritual keagamaan hanya dilakukan di antara mereka yang satu keyakinan, akan tetapi persiapan dan proses pemakaman dilakukan secara bersama-sama".

Begitu juga yang disampaikan seorang Muslim dengan suami seorang mualaf yang dulu beragama Budha, dan tinggal bersama mertuanya yang masih beragama Budha. Pada saat Idul Kurban, daging dibagi secara merata kepada seluruh penduduk tidak hanya umat Islam saja. Idul Kurban bukan hanya milik umat Islam akan tetapi merupakan rasa syukur kepada Tuhan yang dapat dinikmati bersama.

Mayoritas penduduk Girikarto sebenarnya beragama Islam. Karakter Islamnya adalah Islam Jawa yang masih kental dengan budaya kejawen. Kekuatan Islamnya hanya pada ritual dan nilai budaya, bukan syariat Islam yang sesungguhnya. Karena itu, ketika muncul organisasi Gerakan Rakyat Merdeka (Gerinda) yang dipimpin oleh Wisnu Wardana (kerabat Keraton), seorang Budhis dan Ketua Perhimpunan Budha di Yogyakarta di era tahun 1980, banyak umat Islam di Wiloso dan Girikarto yang berpindah ke agama Budha. Perpindahan ini di samping dilatarbelakangi pemahaman agama Islam yang rendah, di sisi lain karena situasi politik pasca penyisiran kemelut eks PKI oleh Orde Baru. Salah satu jalan keselamatan itu penduduk diajak mengikuti Gerinda dan menerima keyakinan Budha. Kekhawatiran pembantaian terhadap eks PKI yang akan menudingkan kepada penduduk Islam itulah yang membuat umat Islam ikut bergabung dengan Gerinda dan pindah ke agama Budha. Perpindahan agama secara massal itu baru diketahui di tahun 1983 dimana hasil sensus penduduk menunjukkan bahwa mayoritas penduduk Wiloso dan Girikarto (lebih dari 1000 orang) telah 
beragama Budha dan hanya 9 KK yang bertahan beragama Islam.

Perpindahan agama umat Islam ke dalam Budha semata-mata didasarkan damai, ketulusan dan kecocokan misi, visi, dan nilainilai yang diajarkan sang Budha. Masyarakat melihat ajaran sang Budha sangat cocok dengan tuntunan budaya Jawa yang mereka jalani turun temurun. Sang Budha mengajarkan cinta kasih sesama makhluk. Kesadaran cinta kasih itu terlihat dari ajaran tidak boleh memakan daging sebagai bentuk penghormatan jiwa makhluk Tuhan. Budha meyakini bahwa dalam semua doa agama mana pun mengandung kebaikan yang universal. Salam yang ada dalam Islam, dibalas dan diikuti salam juga oleh Budhis meskipun sebagian umat Islam mengatakan doa kami (Budhis) sesat. Bagi Budha, semua doa itu harapan kebaikan bagi sesama, karenanya setiap kebaikan itu harus dihormati sebagai yang baik. Pandangan inilah yang melunakkan sikap Budha untuk toleransi dengan yang lain. Bahkan, kami umat Budha mengikhlaskan anak dan keluarga kami pindah agama. Karena kami meyakini, semua agama berasal dari Tuhan Semesta hanya jalannya yang berbeda. Akan tetapi semua itu menuju pada Sang Hyang Widi, Tuhan Esa.

Hubungan yang cair dan akomodatif antara Islam dan Hindu dalam masyarakat Jawa apabila ditinjau secara antropologis, masyarakat Jawa memiliki kedekatan dengan Hindu dan Budha (Ismawati, 2000). Kedekatan itu terlihat dari konsep kekerabatan, kepercayaan animisme dan dinamisme. Kepercayaan pada animisme dimanifestasikan pada keyakinan akan adanya roh-roh pada benda-benda, tumbuhtumbuhan, hewan, dan juga manusia sendiri. Semua yang bergerak dianggap hidup dan memiliki roh yang berwatak baik dan buruk. Untuk mendapatkan kebaikan dan menolak keburukan, perlu dilakukan pemujaan pada tempat-tempat yang tinggi sebagai wujud ketinggian sang dewa. Sedangkan kepercayaan pada dinamisme, dimanifestasikan pada kekuatan-kekuatan alam yang menentukan seluruh kehidupan termasuk manusia. Kepercayaan dinamisme meyakini bahwa di atas kekuatan alam terdapat kekuatan adikodrati yang hanya bisa ditempuh oleh seseorang melalui kebathinan. Untuk mendapatkan kebathinan yang sempurna harus melakukan lakon prihatin, perih ing batin dengan cara cegah dahar lawan guling, mutih, ngasrep, dan berpuasa pada hari-hari wetonan (Ismawati, 2000).

Masyarakat Girikarto yang sinkretis itu memiliki toleransi keagamaan yang tinggi. Setidaknya ada tiga prinsip umum dalam merespons keanekaragaman agama. Pertama, logika bersama, Yang Satu yang berwujud banyak. Kedua, agama sebagai alat, karenanya wahyu dan doktrin dari agamaagama adalah jalan atau dalam tradisi Islam disebut syariat untuk menuju Yang Satu. Ketiga, pengenaan kriteria yang mengabsahkan, maksudnya mengenakan kriteria sendiri pada agama-agama lain" (Suryana, 2011). Dengan demikian toleransi di tengah pluralitas keagamaan masyarakat Girikarto sangat mungkin tercipta dan terjaga hingga kini. Ide dan makna keagamaan itu menjadi dasar toleransi di tengah pluralitas masyarakat. Dapat disimpulkan bahwa toleransi merupakan konsep keagamaan yang berbaur dengan pluralitas tradisi Jawa (HinduBudha, animisme, dinamisme, dan Islam) yang membentuk ide, nilai, tradisi, sistem sosial sebagai satu kesadaran hidup damai dan rukun di antara masyarakat. Spirit toleransi dalam kemajemukan itu tak lain merupakan kesadaran bermasyarakat, berbangsa, dan bernegara dalam konteks Pancasila. Pancasila adalah asas-asas yang terbangun dari nilainilai sosial, budaya, dan agama masyarakat yang diyakini, dijiwai, dan ditaati. Pengutamaan pada keharusan dan solidaritas sosial ketimbang kehendak personal internal agama menjadi indikator bahwa Pancasila adalah nilai-nilai yang hidup melampaui agama dan keyakinan budaya yang ada. Indonesia dengan populasi muslim terbesar di dunia memilih jalan yang berbeda dalam kehidupan beragama dan bernegara tidak seperti Saudi arabia dan tidak sekuler seperti Turki (Seo, 2012), namun memilih jalan tengah untuk mengakomodir toleransi keagamaan dengan agama selain Islam yang disatukan dengan Pancasila

Di samping itu, pemahaman universalitas

Jurnal Civics: Media Kajian Kewarganegaraan |93 
ketuhanan masyarakat Girikarto yang sejalan dengan sila pertama Pancasila, menjadi tuntunan nilai dan kesadaran perlunya saling menghormati di tengah perbedaan yang ada. Keteraturan, keseimbangan, dan keindahan dalam hidup hanya bisa terwujud melalui kesadaran dan sikap mengendalikan diri dan cinta sesama. Cinta sesama itu hanya bisa diwujudkan lewat kebersamaan dan kegotongroyongan. Pemahaman dan kesadaran masyarakat Girikarto ini merupakan modal pertama dalam membangun toleransi keagamaan.

Modal kedua, melalui inklusivitas keagamaan yang berdimensi sosial. Idul Kurban dengan penyembelihan hewan kurban adalah ritual keagamaan Islam yang berdimensi sosial. Masyarakat Girikarto menyelenggarakan pemotongan hewan kurban di Masjid Huswatun Hasah dan Abu Bakar. Pemotongan daging kurban dibagikan kepada seluruh masyarakat baik Islam, Budha, dan Kristen. Pembagian daging kurban kepada seluruh masyarakat ini sudah menjadi tradisi dan hingga kini masih dilaksanakan. Dalam ritual lain misalnya Ruwah, Labuh atau Rasulan, yang meskipun sangat lekat dengan tradisi, pelaksanaannya dilakukan bersama-sama antara umat Budha dan Islam. Ritual tradisi Ruwah ini memiliki makna simbol rasa syukur masyarakat atas hasil panen. Konsep rasa syukur itu dilekatkan pada kebersamaan. Ibu-ibu bekerja bersama di dapur mempersiapkan tumpeng untuk ritual kenduren bagi para leluhur dan bagi Tuhan yang memberi rezeki. Mereka berziarah ke makam leluhur sebagai wujud penghormatan. Menurut Geertz (1973), agama tidak lain sebuah sistem simbol yang memberikan penganutnya ide-ide. Simbol-simbol dalam agama tersebut menciptakan perasaan dan motivasi yang kuat, mudah menyebar dan tidak mudah hilang dalam diri seseorang (penganutnya), atau simbol agama tersebut menyebabkan penganutnya melakukan sesuatu (misalnya ritual), karena dorongan perasaan yang sulit didefinisikan dan juga sulit dikendalikan. Kekuatan perasaan itu muncul karena agama membentuk konsepkonsep tentang tatanan seluruh eksistensi. Maksud agama terpusat pada makna final (ultimate meaning), suatu tujuan pasti bagi dunia.

Tradisi Ruwahan lainnya, yaitu dengan mengirim doa bagi para leluhur mereka yang telah tiada. Anggota masyarakat yang mempunyai anggota keluarga yang telah meninggal dunia, mengadakan Ruwahan di rumah masing-masing. Mereka yang beragama Islam, mengadakan doa bersama dengan berdasarkan ajaran Islam, seperti tahlilan. Tuan rumah yang beragama Budha, yang memperingati kematian leluhur yang juga Budhis, mengadakan doa bersama ala Budha. Tetapi, siang harinya, atau keesokan harinya, selalu diikuti dengan besik ke makam leluhur tersebut, dengan sesajen-sesajen.

Modal ketiga, adalah kerja sosial dengan apa yang disebut dengan "turun gunung." Turun gunung bukanlah merupakan kegiatan yang berdimensi agama, namun perannya sangat besar dalam menjaga kerukunan antar umat beragama. Turun gunung ini sebuah kegiatan masyarakat untuk memelihara, membangun, dan mengembangkan kebersamaan dalam masyarakat. Seperti, bersih-bersih desa, memperbaiki fasilitas publik, membangun rumah warga yang tertimpa musibah atau tidak mampu, dan memperbaiki dan membangun rumah ibadah pasca bencana. Bakti sosial yang dilakukan secara bergotong royong dapat menjadi sarana komunikasi sehingga relasi antar masyarakat senantiasa harmonis. Ikatan sosial melalui kegiatan sosial ini di samping memberi reward, di sisi lain juga dapat memberi punishment bagi mereka yang tidak mengindahkannya.

Peninggalan Hindu-Budha yang berkorelasi dengan animisme dan dinamisme dapat menjelaskan relasi dan karakteristik sistem budaya sinkretis dan agama masyarakat Girikarto. Sehingga tidak terlalu sulit untuk menerima Budha dan kemudian kembali ke Islam. Seperti yang dikatakan Geertz (1973), bahwa dalam masyarakat Jawa, agama merupakan bagian dari sistem budaya. Dalam agama terdapat ritual budaya, sebaliknya, dalam budaya terdapat ajaran dan ritual agama tentang ketuhanan dan kesemestaan yang dilakukan dalam bentuk pemujaan dan sesajen. Masyarakat 
merupakan entitas yang kompleks yang di dalamnya tidak hanya terdapat komponen material dan struktur satu komunitas manusia semata, melainkan terdapat sistem yang lebih luas dari itu, yakni meliputi ide, adat istiadat, perilaku, simbol dan institusi-institusi dalam suatu masyarakat. Simbol-simbol dalam agama tersebut menciptakan perasaan dan motivasi yang kuat, mudah menyebar dan tidak mudah hilang dalam diri seseorang (penganutnya), atau simbol agama tersebut menyebabkan penganutnya melakukan sesuatu (misalnya ritual), karena dorongan perasaan yang sulit didefinisikan dan juga sulit dikendalikan. Kekuatan perasaan itu muncul karena agama membentuk konsepkonsep tentang tatanan seluruh eksistensi. Maksud agama terpusat pada makna final (ultimate meaning), suatu tujuan pasti bagi dunia. Konsepsi-konsepsi tentang dunia dan serangkaian motivasi serta dorongandorongan yang diarahkan oleh moral ideal adalah inti agama, yang diringkas Geertz dalam dua term, pandangan hidup dan etos (Geertz, 1973).

Berbeda dengan masyarakat Girikarto yang sangat kental dengan nuansa kejawen, masyarakat Kotabaru yang puritan memiliki sikap toleransi yang lebih konseptual. Sebagaimana diketahui, ada dua tempat ibadah yang cukup representatif di wilayah Kotabaru, yakni Gereja HKBP dan Masjid Syuhada. Islam maupun Kristen yang ada di Kotabaru, dalam konteks pemahaman keagamaan, keduanya termasuk puritani. HKBP menganut Kristen Protestan, sementara Masjid Syuhada mayoritas Muhammadiyah. Keduanya memiliki prinsip keagamaan yang kuat karenanya toleransi yang diberikan pun sangat formal. Artinya, toleransi itu hanya sepanjang dalam mendukung dan menciptakan suasana kondusif bagi pelaksanaan keagamaan masing-masing.

Meski karakter keagamaan berbeda, namun di dalam komunitas HKBP (Huria Kristen Batak Protestan) dan Masjid Syuhada Kotabaru Yogyakarta sedikit memiliki persamaan dalam konteks toleransi keagamaan. Prinsip toleransi yang dipahami kristiani HKBP dalam menjalin komunikasi dengan komunitas Islam Masjid Syuhada misalnya, dengan saling berkomunikasi atau memberi tahu jika ada acara di antara keduanya. Komunikasi ini penting mengingat posisi keduanya yang saling berdekatan dan ruang parkir yang sangat terbatas. Bentuk penguatan internal Kristen ialah dengan menjadikan Alkitab menjadi pedoman bersama umat Kristen dalam melakukan ibadah. Terkait dengan pluralisme kristiani menjelaskan bahwa hal tersebut sudah diatur dalam Alkitab (perjanjian baru). Kaum Kristiani menekankan menahan diri, jangan pernah membalas kekerasan dengan kekerasan. Prinsipnya, moral harus dikembalikan ke tataran agama. Untuk menghindari konflik keagamaan, sudah sejak lama dalam dakwah kami tidak menggunakan istilah surga yang abstrak itu. Kristen mengajarkan adalah perilaku-perilaku baik dalam diri, keluarga, masyarakat, dan negara. Jika ada tekanan dan gesekan keagamaan dari kelompok Islam, sebagai hamba, kami mengajarkan keharusan pasrah, dan terpenting senantiasa berbuat baik. Fungsi agama itu maksimal, maka agama tidak boleh berpolitik karena tanggungjawab agamawan adalah mengurusi umat.

Secara historis keberadaan bangunan di Kotabaru merupakan bangunan peninggalan jaman Penjajahan Belanda. Adanya gereja HKBP dan Gereja Katolik dibangun dari masa penjajahan pada tahun 1923 yang di domisili oleh orang berkulit putih. Keinginan umat Muslim pada saat itu yang tidak mempunyai tempat ibadah, adalah mendirikan masjid. Pada tahun 1952 dibangunlah Masjid Syuhada atas kesepakatan Ir Soekarno dan Sri Sultan Hamengkubuwono IX dengan ketua yayasan Kanjeng Jatiningrat (dari keraton). Namanama jalan yang ada di Kotabaru adalah nama-nama pahlawan pada saat itu di zaman penjajahan Belanda. Sebelum ada masjid Syuhada, umat Muslim Kotabaru dan sekitarnya sempat meminjam gereja Kristen (Protestan) untuk mengadakan pengajian dan salat Jumat berjamaah.

Sementara, Masjid Syuhada sebagai tempat beribadah umat muslim di Kotabaru tergolong besar. Masjid ini mendapat julukan sebagai cagar budaya yang memiliki

Jurnal Civics: Media Kajian Kewarganegaraan |95 
bangunan tua dan sampai saat ini masih digunakan sebagai temapat ibadah setiap hari. Mengenai masalah toleransi keberagaman yang ada di Kotabaru, sampai saat ini di lingkungan sekitar masjid khususnya di Kotabaru kondisinya aman. Tidak ada konflik antar agama sampai saat ini. Meskipun letak masjid Syuhada sekompleks dengan Gereja Kristen dan Gereja Katolik yang jaraknya hanya 100-meter saja. Kegiatan-kegiatan yang selama ini berlangsung di Masjid Syuhada maupun kegiatan yang berlangsung di Gereja selalu berjalan berdampingan. Ketika masjid Syuhada mengadakan acara tempat parkir sempat meminjam lahan parkir gereja, kemudian sempat dari pihak gereja ketika ada acara juga sempat meminjam area parkir masjid.

Masjid Syuhada sebagai masjid yang relatif besar di Kota Yogyakarta memiliki berbagai macam kegiatan diantaranya adalah kajian rutin yang sudah terjadwal. Mulai dari Pengajian Putri Yogyakarta (PPY), pengajian Husnul Khotimah untuk para lansia, pengajian Al- Hijrah dan terakhir adalah pengajian Sajadah yang diadakan setiap sabtu pagi dan keliling di beberapa masjid yang ada di Yogyakarta.

Metode yang digunakan oleh masjid Syuhada untuk menjaga keharmonisan antar umat ialah tetap menjaga komunikasi dengan tidak melakukan intimidasi. Bentuk komunikasi yang dilakukan adalah ketika gereja atau masjid ingin mengadakan suatu acara maka memberi tahu untuk hal parkir satu minggu sebelum acara dimulai. Peran pemimpin masjid/takmir dalam menjaga kebersamaan ialah menjaga toleransi untuk umat semuanya, tidak pernah melibatkan unsur politis. Pernah ada salah seorang yang berpaham Islam radikal yang mau melakukan demo di Jakarta, dengan memberi instruksi untuk berkumpul di masjid Syuhada. Akan tetapi dari pihak yayasan tidak membolehkan. Masjid Syuhada harus bersih dari unsur politik. Yayasan Masjid Syuhada tidak pernah melarang jamaahnya untuk ikut berdemo, tetapi jangan membawa nama-nama masjid. Hal ini berbanding lurus dengan hasil penelitian Sakai dan Fauzia (2014) dan Freedman (2009) bahwa muslim Indonesia menjadi Islamis yang kurang politis, dan lebih banyak lagi Islamis sosiokultural yang berusaha menganjurkan moralitas Islam dan toleransi antar umat beragama.

Pola asah, asih, asuh yang dilakukan pemerintah, agamawan, dan tokoh masyarakat kepada masjid ini pun bisa dikatakan cukup membantu. Kerja sama dengan masyarakat dan kepolisian dalam mengamankan kegiatan yang besar terjalin dengan baik. Masjid ini tidak di danai oleh pemerintah, pembangunan dan kegiatan berjalan dengan biaya dari para donatur dan jamaah yang aktif.

Baik HKBP dan Yayasan Masjid Syuhada terbentuk dan berkembang dalam masyarakat majemuk yang kental dengan tradisi budaya baik budaya kolonialis maupun budaya Jawa itu sendiri. HKBP dengan tradisi paham rasionalis yang diwariskan kolonialis Belanda mempengaruhi dalam cara berpikir, berkomunikasi, dan mengambil keputusan. Yayasan Masjid Syuhada, Muhammadiyah Jawa namun juga kental tradisi paham rasionalisnya sehingga komunikasi dan relasi keduanya bisa bertemu dalam komunikasi nalar moral publiknya.

\section{Simpulan}

Toleransi merupakan konsep keagamaan yang berbaur dengan pluralitas tradisi Jawa (Hindu-Budha, Animisme, Dinamisme, dan Islam). Percampuran itu membentuk ide, nilai, tradisi, sistem sosial sebagai satu kesadaran hidup damai dalam masyarakat. Kesadaran toleransi itu adalah kesadaran komunal bagi solidaritas kemasyarakatan, kebangsaan, dan kenegaraan. Penerapan toleransi yang melampaui arus utama keyakinan (internum) masing-masing, disamping dilatarbelakangi oleh sinkretisme, juga dilandasi wujud spirit Pancasila dalam kehidupan masyarakat Girikarto dan Kotabaru Yogyakarta. Islam dan Budha di Girikarto Panggang Gunung Kidul yang sinkretis dan HKBP dan Masjid Syuhada (Protestan dan Islam) yang puritanis di Kotabaru Yogyakarta terdapat persamaan nilai dasar yang mampu membangun toleransi keagamaan yakni pertama, pemahaman keagamaan yang inklusif sebagai satu kebutuhan dalam kerukunan dan 
keharmonisan umat beragama. Kedua, komunikasi dalam relasi keagamaannya. Ketiga, melibatkan unsur-unsur kegiatan sosial dalam menjalin relasi dan komunikasi itu. Perbedaannya, pertama, Islam dan Budha di Girikarto mempunyai paham universalis dan tujuan akhir kehidupan pada yang Satu. Semua agama memiliki tujuan yang sama dan akan kembali kepada Tuhan yang Satu. Karena itu, kehidupan masyarakat merupakan satu kesatuan untuk menjaga keteraturan, keseimbangan, dan keselarasan bersama. Sementara HKBP dan Masjid Syuhada (Protestan dan Islam) yang puritanis di Kotabaru meyakini secara rasional bahwa agama merupakan tuntunan Tuhan yang mengandung kebenaran tersendiri. Karena perbedaan itu merupakan kehendak Tuhan. Kedua, Islam dan Budha di Girikarto memaklumkan berpindah-pindah agama. Sementara HKBP dan Masjid Syuhada (Protestan dan Islam) di Kotabaru Yogyakarta tidak membenarkan hal itu.

\section{Referensi}

Budiyono, B. (2014). Hubungan negara dan agama dalam negara Pancasila. Fiat Justisia, $\quad 8(3), \quad$ 410-423. https://doi.org/10.25041/fiatjustisia.v8n o3.305

Freedman, A. L. (2009). Civil society, moderate Islam, and politics in Indonesia and Malaysia. Journal of Civil Society, $5(2)$, 107-127. https://doi.org/10.1080/1744868090315 4907

Fuad, F. (2012). Islam dan ideologi Pancasila,sebuah dialektika. Lex Jurnalica, 9(3), 164-170.

Geertz, C. (1973). The interpretation of cultures. New York: Basic Book.

Ismawati. (2000). Budaya dan kepercayaan Jawa pra-Islam. In Islam \& Kebudayaan Jawa (hal. 3-24). Yogyakarta: Gama Media.
Jones, P., Bradbury, L., \& Le Boutillier, S. (2009). Pengantar teori-teori sosial dari teori fungsionalisme hingga postmodernisme. (A. F. Saifuddin, Penerj.). Jakarta: Yayasan Obor Indonesia.

Kamaruddin. (2013). Dimensi sila "Ketuhanan Yang Maha Esa" dalam perspektif HAM Islam. IN RIGHT Jurnal Agama dan Hak Azazi Manusia, Vol. 3(No. 1).

Kartohadiprodjo, S. (2010). Pancasila sebagai pandangan hidup bangsa Indonesia. Yogyakarta: Gatra Pustaka.

Merton, Robert, K. (1967). Social theory and social structure. New York: The Free Press.

Parsons, T. (1961). Theories of society foundations of modern sociological theory. New York: The Free Press.

Ruhana, A. S. (2016). Relasi Muslim-Buddhis di Panggang, Gunung Kidul, D.I. Yogyakarta. Jurnal Multikultural \& Multireligius, 15(1), 23-37.

Sakai, M., \& Fauzia, A. (2014). Islamic orientations in contemporary Indonesia: Islamism on the rise? Asian Ethnicity, 15(1), 41-61. https://doi.org/10.1080/14631369.2013. 784513

Seo, M. (2012). Defining "religious" in Indonesia: Toward neither an Islamic nor a secular state. Citizenship Studies, $16(8)$, 1045-1058. https://doi.org/10.1080/13621025.2012. 735028

Suryana, T. (2011). Konsep dan aktualisasi kerukunan antar umat beragama. Pendidikan Agama Islam -Ta'lim, 9(2), 127-136.

Sutiyono. (2011). Benturan budaya Islam: Puritan dan sinkretis. Jakarta: Kompas. 